\title{
Obituary
}

\section{Dr Jean Nitsch}

ON June 28, 1971, Dr Jean P. Nitsch died on the Brittany coast while diving to study marine plants. It was typical that his zest for observation and inquiry should lead him into new and unfamiliar techniques, and his death, at 49, has robbed France and plant physiology of a very versatile investigator.

Born on September 15, 1921, Nitsch's career was divided between his native France and the USA where he was equally at home and as well known. As in the case of most of his genera. tion the Second World War interrupted his Baccalaureate studies, but in due course he acquired diplomas in France from the University of Grenoble (1943), the Sorbonne (1946) and as Ingénieur Agronome de l'Institut National Agronomique de Paris (1947). But it was his association with Professor F. W. Went at the California Institute of Technology, Pasadena, which culminated in a doctorate awarded in 1950, that first brought him to the attention of the scientific world. The title of his thesis, The Role of Plant Hormones in Fruit Development, indicates the trend of Nitsch's work throughout. He was dedicated to the interpretation of the controls of growth through chemical regulation and strongly motivated to work in areas beneficial to horticulture.

Even before the presentation of his thesis Nitsch's work became known because of his attempts to culture immature fruits aseptically, in vitro, and early papers appeared both in France and in the USA ${ }^{1-3}$. In this early work a favourite experimental material was the multiple strawberry fruit, and Nitsch drew attention to the role of achenes in the development of the receptacle and of auxin (IAA) in the growth and morphogenesis of the strawberry. From this starting point Nitsch moved rapidly to the culture of excised ovaries, to the general use of proliferated callus cultures in the study of growth, and to a variety of investigations concerned with the role of hormones in sex expression and the development of fruits ${ }^{4,5}$. His interest in these fruits was maintained at $\mathrm{Har}$ vard (1950-51) as a postdoctoral research fellow and, after a brief return to France, at Harvard again as a research fellow (1953-55) where he worked in the laboratory of, and was influenced by, Professor R. H. Wetmore.

From 1955 to $1958 \mathrm{Dr}$ Nitsch was an assistant professor at Cornell University and was in charge of a course on plant physiology applied to horticulture. His role in the Department of Floriculture at Cornell allowed him to exploit his interest in the use of aseptic culture procedures, while he also interested himself in the problems of plant propagation, in photoperiodism, and in the chemical induction and regulation of growth.

After returning permanently to France in 1958 Nitsch was associated (in obvious continuity with his experiences at Pasadena) with the development and use of the. Phytotron, a large installation for the environmental control of the growth of plants, at Gif-surYvette near Paris, and he served as deputy director there from 1958-62. It is in this capacity and successively as Directeur-Adjoint d'Institut de Recherche au CNRS (1962-69) and as directeur du Laboratoire de Physiologie Pluricellaire from 1969 until his death that Nitsch's scientific stature came to be recognized internationally. Some 35 investigators from 16 countries were attracted to the Phytotron during the years of his association with it. Nitsch was also appointed to an academic position in France as professeur à 1'Institut National Agronomique in a chair designated for plant physiology.

In conclusion, certain areas of Nitsch's wide range of interest may be mentioned. The early work on auxin and growth promoting substances prompted him to show by chromato. graphic means that many naturally occurring substances had auxin-like activity. This interest was to make him a welcome participant and contributor to a succession of international conferences on plant growth regulating substances. Nitsch contributed to the conference held at Wye, Kent, in $1955^{\circ}$, and the maintained interest in chemical regulation of plant growth led him to organize a similar international conference at Gif, the proceedings of which were published in 1964 under his editorial supervision ${ }^{7}$. Any full current treatment of the chemical controls of growth must note Nitsch's work on cell division or cell enlargement, using a variety of assay systems and as brought about by a variety of substances. His work has involved auxins, cytokinins, gibberellins as well as substances and extracts held to be more specifically associated with flowering 8,9 .

In logical continuation of Nitsch's interests in aseptic culture of somatic tissues and floral organs, he intervened most effectively in the culture of hap. loid cells from anthers of tobacco ${ }^{10}$ and studied their development into haploid plants. By subsequently doubling their chromosome numbers, Nitsch obtained, in this way, completely homozygous plants from certain mutant forms and published in this field earlier this year ${ }^{11}$. Nitsch's published work includes at least 154 papers and a number that will appear posthumously.

No reference to Jean Nitsch would be complete, however, without tribute to his friendliness and the hospitality that he and his wife, Colette, extended to so many scientific visitors to France, his laboratory, and his home in Gif. $\mathrm{He}$ is survived by his wife, Dr Colette Nitsch, and by two children.

CR Acad. Sci., Paris, 229, 445 (1949).

2 Science, 110, 499 (1949).

3 Amer. J. Bot., 37, 211 (1950)

4 Quarterly Review of Biology, 27, 33 (1952).

Ann. Rev. Plant Physiology, 4, 199 (1953).

- In Chemistry of Plant Growth Substances (edit. by Wain, R. L., and Wightman, F.), 3 (Butterworths, London, 1955).

7 Régulateurs Naturels de la Croissance Végétale (edition du Centre National de la Recherche Scientifique, Paris).

8 Ruhland Handbuch der Rflanzenphysiologie, 15 (1), 1537 (1965).

9 In Plant Physiology: A Treatise (edit. by Steward, F. C.), 6A, 403 (Academic Press, New York City, 1971).

10 Science, 165, 85 (1969).

11 Pollen Development and Physiology (edit. by Heslop-Harrison, J.), 234 (Butterworths, London, 1971). 